$\mathrm{A} \int_{\text {ass }} \underset{0976-272 \times \mathrm{x}}{\mathrm{H}}$

Received : 23.05.2013

Revised : 06.11.2014

Accepted : 20.11.2014
Members of the Research Forum

Associated Authors:

${ }^{1}$ Department of Fruit Science, College of Horticulture, Rajmata Vijayaraje

Scindia Krishi Vishwavidyalaya,

MANDSAUR (M.P.) INDIA
Author for correspondence : RAJESH TIWARI

Department of Fruit Science, College of Horticulture, Rajmata Vijayaraje

Scindia Krishi Vishwavidyalaya,

MANDSAUR (M.P.) INDIA

Email : rt_jnkvv@yahoo.com
THE ASIAN JOURNAL OF HORTICULTURE

Volume 9 | Issue 2 | Dec., 2014|439-442

Visit us -www.researchjournal.co.in

\title{
Effect of intercropping on plant and soil of Dashehari mango orchard under low productive environments
}

\section{RAJESH TIWARI AND B.S. BAGHEL ${ }^{1}$}

ABSTRACT : An intercropping trial was conducted on 7-years old mango cv. DASHEHARI orchard planted at spacing of $7.0 \mathrm{~m}$ x $7.0 \mathrm{~m}$ spacing and growing under rainfed medium black clay loam of average fertility and well drained soil to identify the suitable and profitable intercrops. The intercrops were grown with different intercropping systems like mono, companion and sequential are pigeon pea, tomato, cluster bean, okra, black gram, soybean, cowpea, maize, mustard, coriander and bengal gram. The results of two years of investigation indicated that number of fruits was maximum in mango with companion intercropping system of pigeonpea + soybean followed by sequential intercropping system of cowpea - bengal gram did not differ significantly. Fruit length, fruit diameter and fruit weight was also highest with companion intercropping system of pigeon pea + soybean closely followed by sequential intercropping system of cowpea-bengal gram. Fruit quality of mango did not significantly differ among the intercrops treatment. Highest net return was calculated from mango + (pigeonpea + tomato) combination (Rs. 81077.50) followed by mango + cowpea-bengal gram (Rs. 71677.13) and mango + tomato (Rs. 67034.38). Nitrogen concentration in the orchard soil was improved due to growing of leguminous crops while phosphorus and potassium were depleted in all the cases.

KEY WORDS : Inter-cropping, Mango, Rainfed

HOW TO CITE THIS ARTICLE : Tiwari, Rajesh and Baghel, B.S. (2014). Effect of intercropping on plant and soil of Dashehari mango orchard under low productive environments. Asian J. Hort., 9(2) : 439-442. 